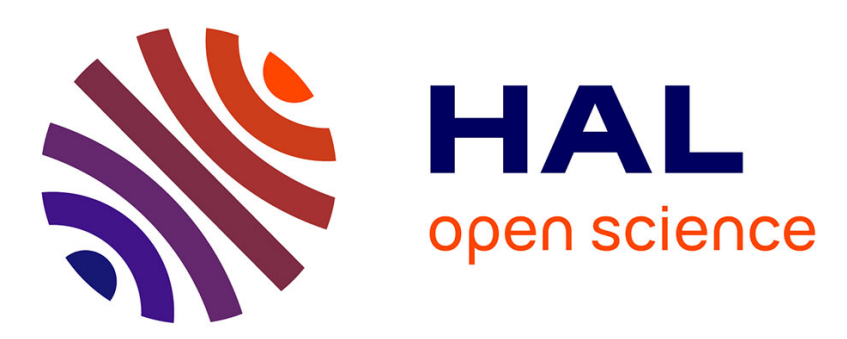

\title{
Emotional and behavioral difficulties in children growing up homeless in Paris. Results of the ENFAMS survey
}

M Roze, S Vandentorren, C Vuillermoz, Pierre Chauvin, M Melchior

\section{To cite this version:}

M Roze, S Vandentorren, C Vuillermoz, Pierre Chauvin, M Melchior. Emotional and behavioral difficulties in children growing up homeless in Paris. Results of the ENFAMS survey. European Psychiatry, 2016, 38, pp.51-60. 10.1016/j.eurpsy.2016.05.001 . hal-01372440

\section{HAL Id: hal-01372440 \\ https://hal.sorbonne-universite.fr/hal-01372440}

Submitted on 27 Sep 2016

HAL is a multi-disciplinary open access archive for the deposit and dissemination of scientific research documents, whether they are published or not. The documents may come from teaching and research institutions in France or abroad, or from public or private research centers.
L'archive ouverte pluridisciplinaire HAL, est destinée au dépôt et à la diffusion de documents scientifiques de niveau recherche, publiés ou non, émanant des établissements d'enseignement et de recherche français ou étrangers, des laboratoires publics ou privés. 
Emotional and behavioral difficulties in children growing up homeless in Paris.

Results of the ENFAMS survey.

M. Roze ${ }^{1}$, S. Vandentorren ${ }^{1,2}$, C. Vuillermoz ${ }^{1}$, P. Chauvin ${ }^{1}$, M. Melchior ${ }^{1}$

${ }^{1}$ Sorbonne Universités, UPMC Univ Paris 06, INSERM, Institut Pierre Louis

d'Épidémiologie et de Santé Publique (IPLESP UMRS 1136, Équipe de Recherche en

Épidémiologie Sociale), F75012, Paris, France

${ }^{2}$ Institut de Veille Sanitaire, Saint-Maurice, France 


\begin{abstract}
Purpose: Children growing up in homeless families are disproportionately more likely to experience health and psychological problems. Our objective was to describe social, environmental, individual and family characteristics associated with emotional and behavioral difficulties among homeless children living in the Paris region.
\end{abstract}

Methods: Face-to-face interviews with a representative sample of homeless families were conducted by bilingual psychologists and interviewers between January and May 2013 ( $n=343$ children ages 413 years). Mothers reported children's emotional and behavioral difficulties (Strength and Difficulties Questionnaire - SDQ), family socio-demographic characteristics, residential mobility, and parents' and children's physical and mental health. Children were interviewed regarding their perception of their living arrangements, friendships and school experiences. We studied children's SDQ total score in a linear regression framework.

Results: Homeless children had higher SDQ total scores than children in the general population of France, (mean total score $=11.3$ vs $8.9, p<0,001)$. In multivariate analyses, children's difficulties were associated with parents' region of birth (beta=1.74 for Sub-Saharan Africa, beta=0.60 for Eastern Europe, beta $=3.22$ for other countries, $p=0.020$ ), residential mobility (beta $=0.22, p=0.012$ ), children's health (beta=3.49, $p<0.001$ ) and overweight (beta=2.14, $p=0.007$ ), the child's sleeping habits (beta $=2.82, p=0.002$ ), the mother's suicide risk (beta $=4.13, p<0.001$ ), the child's dislike of the family's accommodation (beta=3.59, $p<0.001$ ) and the child's experience of bullying (beta=3.21, $p=0.002$ ).

Conclusions: Children growing up homeless experience high levels of psychological difficulties which can put them at risk for poor mental health and educational outcomes long-term. Access to appropriate screening and medical care for this vulnerable yet underserved group are greatly needed.

Keywords: homeless, children's mental health, emotional and behavioral difficulties 


\section{Introduction}

Homelessness has increased in recent years in many European countries [1] and is known to be an important determinant of mental health. France is a "corporatist conservative welfare regime", has well-functioning safety nets and the living conditions (access to housing, schooling, health care...) of poor households are still preferable to those in many other countries. But housing inequality is increasing more rapidly than elsewhere, leading to the exclusion of some groups of the population from certain social benefits [1]. In 2013, the ENFAMS survey [2] estimated that over 10,280 homeless families were accommodated in the Paris area, corresponding to approximately 35,000 people including 17,660 children. These estimates do not take into account families housed by friends or relatives, implying that the overall number of families without a stable accommodation is actually higher.

The increase in the number of homeless families in the Paris region in recent years [3] is due to several factors. First, real estate prices have grown drastically in recent years, much more rapidly than household income or the number of subsidized housing units. Second, in France, social benefits are insufficient to reduce financial, job and housing insecurity for single mothers with children. However, in Paris, as in other large cities in Europe, one child out of three does not live with both of his/her parents, and the number of single-parent families among the most socioeconomically deprived groups is even greater. Third, the number of migrants who do not have a visa enabling them to work and access affordable housing has grown. Compared to other European countries, the proportion of foreigners among individuals who are homeless is high in France, and has recently increased (38\% in 2001, $52 \%$ in 2012) [1]. Fourth, applying for sheltered accommodation is a complex process, especially for foreign families who are mobile, socially excluded and often non-francophone [2-4].

General risk factors for psychiatric difficulties in children include: genetic risk factors $[5,6]$, parental and maternal poor physical and mental health [7-13], as well as prenatal [14,15], obstetrical 
complications [16], low socio-economic status (single-parent family, low educational or income level, food insecurity) [17-23], negative life events [11,22], low social networks and support [23], as well as domestic violence [24-26] and child maltreatment [26-30]. Children growing up in homeless families are disproportionately exposed to many of these exposures and experiences.

Additionally, homeless families experience loss of property, disruption of school and community relationships [31], dramatic changes in family routine [32] or residential instability, which may have consequences on children's emotional and behavioral well-being $[10,33,34]$.

Furthermore, factors specific to homeless families may also play a role, including the physical quality, crowding, affordability, place and stability of living arrangements $[10,11,22,29,35]$, as well as children's school experience (e.g. school mobility, absenteeism, educational outcomes and academic achievement) $[36,37]$.

Previous epidemiological surveys on homeless children's emotional and behavioral difficulties were predominantly conducted in the 1980's and 1990's in the United States $[11,38]$. Yet the sociodemographic characteristics and life trajectories, as well as the organization of health care services and their use by homeless populations can vary from one country to another. For instance, in the United States, many homeless families are African-American and single-parent $[24,39]$.

Therefore we aimed to 1) describe emotional and behavioral difficulties in children growing up in homeless families in the context of a large European city - Paris and 2) identify social, environmental, individual and family factors associated with these difficulties. 


\section{Materials and Methods}

\subsection{Sample}

The ENFAMS survey (a French acronym for "Enfants et familles sans logement") [2] was conducted from January to May 2013 to describe the socio-demographic and health characteristics of homeless families in the Paris region (approximately 12 million inhabitants). Following guidelines from France's National Institute of statistics (INSEE), a person is considered to be homeless on any given day if he or she spent the previous night in a sheltered accommodation or slept in a place not intended for living (on the street, in a squat, vehicles, abandoned buildings, public places including streets, parks etc.) [26]. A time-location sampling design was used [2].

First, all housing facilities open to homeless families in the Paris region (e. g. emergency shelters, long-term re-habilitation centers, social hotels and accommodation for asylum seekers) were listed. Emergency shelters are generally characterized by group accommodations that are short term and provide only basic services (e.g. breakfast). Long-stay hostels (rooms in a collective facility but also self-contained flats or hotel rooms), are characterized by stays lasting up to several months and a larger number of services (e.g. access to a kitchen). Asylum seekers are in principle accommodated in special accommodations. However, since the early 2000s, there have been a shortage of beds in these centers, resulting in asylum seekers being accommodated in inexpensive hotels. Second, the number of families and children within each homeless housing facility were estimated in a telephone survey. Third, families were selected using simple random sampling in each selected accommodation. Fourth, one child was randomly chosen in each family among all those younger than 13 years (simple random sampling).

The study design was approved by the French National confidentially Committee (CNIL). 


\subsection{Participation in the ENFAMS survey}

The ENFAMS survey recruited 251 randomly selected housing facilities in the Paris region (82\% participation). In these housing facilities, 1,238 families were selected to participate in the survey (65\% participation) yielding a sample of 801 families. In each family, the mother (or the father if the mother was not present) and one child under the age of 13 years were randomly selected to participate. Families who did not participate in the ENFAMS survey were characterized by younger maternal age (33 vs. 38 years), a higher proportion of men (15.3 vs. $4.6 \%$ among study participants), and a higher proportion of families with two or more children (31.7 vs. $23.1 \%$ among study participants) [2]. Reasons most frequently cited to explain non-participation were: lack of interest (17\%), lack of time (14\%) or the other parent's lack of written consent $(11 \%)$. In this article we studied families with 4-13 year-old children who completed the SDQ.

\subsection{Measures and questionnaires}

Study data were collected in face-to-face interviews with self-report questionnaires completed by the mother and children above 6 years old. Interviews were conducted by trained interviewers and research psychologists in seventeen different languages (Figure 1).

\subsubsection{Children's emotional and behavioral difficulties}

Children's emotional and behavioral difficulties ( 4 to 13 years) were ascertained by their parent using the Strengths and Difficulties Questionnaire (SDQ) [40]. The SDQ is a short behavioral screening questionnaire which includes 25 items divided into 5 subscales: emotional problems, conduct problems, hyperactivity/inattention, peer relationship problems and pro-social behavior. Each item is rated on a 0-2 scale: "not true", "somewhat true" or certainly true". A "Total Difficulties" scale is derived from the sum of scores of the first four scales and ranges 0 to 40 (SDQ total score). If less than 3 items were missing, missing data were imputed by the mean on items that were complete. 
The SDQ can be analyzed as a score or dichotomized using standard cut-offs which match the top $90 \%$ of the distribution in the general population [41]. The SDQ has previously been validated in different languages and cross-cultural settings [41-43] and had good reliability (Cronbach's alpha = $0.76)$ in the present setting.

\subsubsection{Child and parent characteristics}

Participants' characteristics included:

- the child's demographic characteristics: age, sex, country of birth and number of cohabitating siblings;

- parents' socio-demographic characteristics: region of birth (Table 1), legal status, health insurance status, health care use, proficiency in French, migratory trajectory (i.e. time since the family arrived in France), residential mobility (i.e. time since the family became homeless and the number of moves since then), social network (i.e. the number of contacts with family members each month in the preceding 12 months), food insecurity in the preceding 12 months (assessed using the French version of the US Household Food Security Module $[44,45]) ;$

- the child's health: health problems ascertained by the following question: "Is your child being treated for a disease or a health problem that requires specific care?"). respiratory problems (ascertained by the following question: "in the past year, did your child have respiratory problems (a cough, a tightness in his/her chest, wheezing)?") [46]; anemia (ascertained by blood sample collected by nurses); body mass index- BMI (ascertained by study nurses), sleeping habits (assessed by bedtime and time of awakening).mother's negative life event and Post Traumatic Stress Disorders: ascertained by the following question: "At some point in your life, have you experienced a terrible, frightening or horrible event that caused you to have distressing memories or nightmares, to feel isolated or distant from others, to have 
difficulty sleeping or concentrating, or to be excessively nervous?" and the MINI (Mini International Neuropsychiatric Interview [47])

- mother's health: self-reported physical health (very good, good or fair physical health vs. bad or very bad health); major depression (ascertained using the Composite International Diagnostic Interview [48]), suicide risk (ascertained using the Mini International Neuropsychiatric Interview [47]) and experience of domestic violence in the preceding 12 months (based on measures used in a study conducted by the National Institute of Demography : “VIRAGE” [49])”.]);

In secondary analyses, we focused on children aged 6 to 13 years. In France, 6 is the age of compulsory schooling and children up to age 6 can receive free medical preventive care, making 6 years a relevant age in terms of policy. Additionally, in the ENFAMS survey children aged 6 years and older were asked to report their life experiences regarding homelessness (e.g. "Do you feel at home in this shelter?"), their school experience (e.g. "How do you feel at school"), their friendships (e.g. "How many friends do you have?", "When you have secret, who can you tell about it?"), their joys and sorrows (e.g. "What's your best time since the end of holidays?", "Does it happen to you to be sad, to have sorrows or feel sorry for somebody?").

\subsection{Statistical analysis}

Our analysis was based on a sample of 343 children aged 4-13 years with complete data on behavior. Whenever the number of missing observations exceeded 4\%, a "missing data" category was created and included in the analyses.

First, to describe emotional and behavioral difficulties of children growing up in homeless families, we computed the 5 SDQ subscales and compared them with a general population sample of 1,348 French children [50] using student t-tests.

Second, to identify family and child characteristics associated with children's overall emotional and behavioral difficulties, we used a weighted linear regression model. All the variables significantly 
associated with the SDQ total score $(p<0.2)$ in univariate analyses were included in the multivariate analysis. The multivariate analysis systematically adjusted for children's age and sex as well as parents' legal status. Statistical significance was defined as $p=0.05$.

In complementary analyses: 1 ) we restricted our sample to children aged 6 years or older to study child reported characteristics; 2) we checked for interactions between all factors significantly associated with children's characteristics and sex, because of potential differences between boys and girls $[29,51]$; 3) we conducted additional analyses among children of suicidal mothers (extreme group).

All statistical analyses were performed with R; we used the "survey" weighting package to account for study design. 


\section{Results}

\subsection{Descriptive characteristics}

Child and family characteristics are shown in Tables $\mathbf{2}$ and 3. To summarize, $34.5 \%$ of study children were $4-6$ years of age, $47.2 \%$ were male, $42.8 \%$ were born in France (Figure 2), and $88.8 \%$ went to school. Parents' mean age was 35 years and $71.9 \%$ had legal status in France. Almost three-quarters (72.6\%) of families lived in a social hotel, $78.9 \%$ were unemployed and $64.4 \%$ were not proficient in French. Most families (92.9\%) had an income below poverty level (964 euros/month/UC) and were food insecure (84.0\%).

\subsection{Children's emotional and behavioral difficulties}

Overall, $20.8 \%$ of children in the study had a high level of emotional or behavioral difficulties; $28.3 \%$ had a high level of emotional difficulties, $23.9 \%$ had conduct problems, $17.7 \%$ had a high level of symptoms of hyperactivity-inattention and $10.7 \%$ had peer relationship problems (Table 4).

Average SDQ total scores were higher among children in our sample than in the general population of children in France: SDQ total score 11,3 $(95 \% \mathrm{Cl}=[10.4 ; 12.0])$ versus $8,9(95 \% \mathrm{Cl}=[8.6 ; 9.2])(p<0.001)$ [44]. However, among children with high levels of emotional and behavioral difficulties, only $5 \%$ received medical or social care.

\subsection{Univariate regression analysis: factors associated with children's emotional and behavioral} difficulties

As shown in Table 5, factors associated with children's emotional and behavioral difficulties were the following: the child's sex (beta $=1.59$ in boys, $p=0.043$ ), the number of cohabitating siblings (beta= 0.83 for each brother or sister, $\mathrm{p}=0.016$ ), the parent's region of birth (beta $=2.22$ among parents born in Sub-saharan Africa, beta=0.37 among parents born in Eastern Europe and beta=3.43 among parents born in other countries, $p=0.016$ ), social networks (beta $=0.08$ for each contact with family in the month, $p<0.001$ ), the child's health problems (beta=3.19, $p<0.001$ ), the child's respiratory 
problems (beta $=1.69, p=0.001$ ), the child's overweight status (beta=2.02, $p=0.031$ ), the child's sleeping habits (beta associated with bedtime after 10PM=2.18, $\mathrm{p}=0.043$ ), the mother's depression and suicide risk (respectively beta $=3.28, p=0,004$ and beta=5.79, $p<0.001$ ), the mother's poor physical health (beta=3.57, $p=0.011$ ), the child's dislike of the family's accommodation (beta=4.89, $p<0.001)$, and the child's experience of bullying (beta=5.25, $p<0.001$ ).

\subsection{Multivariate analysis}

In the multivariate analysis (Table 6), after adjustment for children's age and sex as well as parents' legal status, factors associated with children's emotional and behavioral difficulties included parents' region of birth (beta=1.74 for Sub-Saharan Africa, beta=0.60 for Eastern Europe, beta=3.22 for other countries, $p=0.020$ ), residential mobility (beta $=0.22, p=0.012$ ), children's health (beta $=3.49, p<0.001$ ), the child's overweight status ( $b e t a=2.14, p=0.007$ ), the child's sleeping habits (beta=2.82, $p=0.002$ ), the mother's suicide risk (beta=4.13, $\mathrm{p}<0.001$ ), the child's dislike of the family's accommodation (beta=3.59, $p<0.001$ ) and the child's experience of bullying (beta=3.21, $p=0.002$ ).

\subsection{Additional analyses}

Our supplementary analyses stratified on children's sex showed that boys whose mother experienced a risk of suicide had a higher level of total difficulties than girls (beta=7.3 vs. 3.9, p-value for interaction test $=0.233$ ).

Among children of suicidal mothers, $52.9 \%$ have a high level of emotional and behavioral difficulties, compared with $16.2 \%$ among children of mothers without suicidal risk $(p<0.001)$. 


\section{Discussion}

\subsection{Main findings}

In our study of children aged 4-13 years growing up in homeless families in the Paris region, we found high levels of emotional and behavioral difficulties. Homeless children's difficulties were associated with children's older age, parent's region of birth (particularly Sub-Saharan Africa), residential mobility, the child's health problems, and overweight, the child's inadequate sleeping habits, poor maternal mental health, as well as the child's negative perception of his/her living arrangements and experience of school bullying. It is important to note that most families in our study were migrant, therefore we are not able to distinguish the contribution of characteristics specific to migrants from those of homelessness.

\subsection{Limitations}

Our study has limitations which need to be acknowledged prior to interpreting the data. First, ENFAMS is a cross-sectional survey and the direction of associations between some of the associated factors studied (for instance, sleeping difficulties or the experience of bullying) and children's emotional and behavioral outcomes is difficult to determine. Nevertheless, it is unlikely that children's difficulties precede several other risk factors identified in this study, such as maternal poor physical health or suicide risk. Second, lack of statistical power and population homogeneity (most families were very poor) may explain why some factors (e.g. food insecurity) were not associated with children's well-being. Additionally, given the disadvantaged socioeconomic status of the sample, it is hard to disentangle the role of homelessness from that of being very poor and being migrants. Similarly, many parents had a high educational level and many mothers were depressed. Most other studies of homeless individuals relied on samples that were of similar size and experienced similar difficulties [39,52-55]. Nevertheless, future research should aim to include larger samples in order to have the possibility to study children's outcomes and associated risk factors in detail. Third, in more than $4 \%$ of cases data were missing on some variables, which led us to include a 'missing data' 
category in our analyses. We have many missing data for the measure of domestic violence because sometimes the partner was present and mothers refused to answer. Reassuringly, multivariate analyses repeated after excluding children with missing data $(n=158)$ showed results consistent with our main findings. Fourth, children's behavior was ascertained by their mother, which may induce reporting bias, particularly if the mother is depressed. Nevertheless, parental reports of children's behavior appear to be valid regardless of parental mental health [56]. Finally, several factors potentially associated with children's emotional and behavioral development were not measured in the ENFAMS survey: family social support (financial assistance, babysitting, housing...) [57-59], parenting style $[60,61]$ and parental use of psychoactive substances [62-64]. Nevertheless, it is unlikely that these characteristics confound associations between maternal mental and physical health or children's experience of bullying and their emotional and behavioral difficulties which we observed.

\subsection{Strengths}

Despite these limits, our study has strengths which deserve to be highlighted. First, the ENFAMS survey includes a multicultural sample of homeless families, who are rarely studied. Second, we used validated measures of maternal and child psychological well-being. Third, the dimensional measurement of children's emotional and behavioral difficulties reflects more closely the spectrum of different behavioral styles than do dichotomous measures [65]. Fourth, the collection of children's reports on their feelings and perceptions of their living conditions makes it possible to identify factors associated with their emotional and behavioral difficulties which may go undetected by parents, such as the child's dislike of his/her shelter or school bullying.

\subsection{Comparison to prior studies}

Contrary to prior research among homeless families, in our study, children's emotional and behavioral difficulties were associated with neither family status, nor parental educational level, employment status, income or food insecurity [11]. Additionally, we found no association with 
maternal depression or PTSD. The high prevalence of maternal depression (23.0\%) and PTSD (18.5\%) and the lack of statistical power may explain this null finding. However, maternal suicide risk - often a manifestation of severe depression - was relevant, indicating the role of maternal health as a determinant of children's well-being.

Our results are consistent with prior research showing that children's health (health problems that requires specific care, respiratory problems, overweight, sleeping habits) $[11,66]$ and maternal mental health $[11,12]$ is associated with children's emotional and behavioral difficulties.

Some authors have underlined the importance for children of feeling that they "have a home" as well as of family and community factors [35]. While bullying is also a risk factor of poor psychological health in children who are not homeless, homeless children may experience bullying more frequently because they do not fit in $[67,68]$. These social difficulties may be encountered both at school and in the housing facility where many families live together. Furthermore, some children could be rejected because of their emotional and behavioral difficulties. Our study shows that the child's dislike of his/her housing facility and experience of bullying at school are associated with psychological difficulties, confirming the importance of these issues.

Overall, our results point to the need for social policies to address school bullying helping children to change address the school climate and monitor children's perception of their life experience.

\subsection{Clinical and policy implications}

We observed high levels of emotional and behavioral difficulties in children whose families are homeless, yet most of them do not have access to appropriate healthcare. Although our study is cross-sectional, several clinical and policy implications can be drawn.

First, family household residential mobility is associated with children's well-being and granting poor families access to stable housing could help improve children's short and long-term outcomes $[10,11,69-73]$. Other countries have implemented policies which reduced homelessness (e.g. the Paavo project in Finland [74] or the "At Home/Chez Soi" project in Canada [75]). In the USA, the aim 
of the "Homeless Prevention and Rapid Re-housing Program" is to quickly place families in stable, permanent housing rather than a continuum of emergency and temporary housing [76]. France made fighting homelessness a 'national priority' for the period 2008-2012, which led to an evaluation of the supply and demand of shelters and housing facilities across the country, the provision of housing facilities for 13,000 individuals and the construction of 150,000 social housing units. Unfortunately, the impact of this program is unknown and it has not been extended beyond 2012 [1]. Housing conditions could improve children's health and housing stability could also facilitate children's and parents' access to mental health care in case of need, provided they are close to a medical center [77]. Furthermore, access to primary care and a regular follow-up makes prevention possible.

Second, barriers to healthcare access, such as parents' lack of knowledge of the health system or lack of proficiency in French, could be addressed by the promotion of free mental health consultations with the possibility of being helped by a trained translator. Such free consultations exist in most university hospitals in France, but the way in which they are implemented and their capacity vary widely. Furthermore, in a more general way, in France there is need for more pediatric mental health professionals; In the USA, the SAMHSA program seems effective in this regard [78]. Moreover access to translation services is generally unsatisfactory. Additionally, public hospitals may be difficult to access and intimidating, therefore access to free primary care services in ambulatory settings should be promoted. Another point is that primary care providers (pediatricians, general practitioners, emergency doctors, etc) are not familiar with children of homeless families. They should become familiar with government and community based services that assist families with unmet social and economic needs. The American Academy of Pediatrics recommends that primary care practionners address issues of access to care and coordinate health care with community-based services [76].

Third, the development of mother and child healthcare centers, which are free and provide preventive health services (e.g. vaccination) to all children regardless of their parents' administrative 
or health care characteristics, could improve access to health care for families with psychological difficulties [77]. In particular, the structures could extend children's follow-up beyond age 6, and improve screening of parent mental health and parental difficulties $[79,80]$. Some studies show the effectiveness of interventions designed to develop children's psychosocial skills and parental abilities [81-86]. They are primarily focused on parents' and children's stress and anger management, relationships with peers, and development of good mother-children interactions. Such interventions could greatly benefit the most socially disadvantaged children, including those who grow up homeless $[87,88]$.

Fourth, interventions increasing awareness about school bullying, specifying rules and social norms against bullying, and providing support and protection for children who are bullied (social worker support, mentoring) have proved successful and should be generalized $[67,68,72,89]$.

\section{Conclusion}

Children growing up in homeless families have high levels of emotional and behavioral difficulties, in part in relation to their mothers' mental health difficulties and their family's difficult living conditions. Access to appropriate medical care for children and their parents could limit the impact of these early difficulties on children's later health and social outcomes. Heightening caretakers' awareness of the role of children's social and school integration with regard to their emotional and behavioral difficulties could improve their long-term educational and health outcomes. Most adult mental health problems begin in childhood, and improving the psychological well-being of children living in poverty offers the possibility of decreasing the level of psychiatric disorders and social inequalities in this area in the next generation. 


\section{Acknowledgements}

The authors are grateful to Carme Caum, Claire Rondet, Delphine Lefeuvre and Laura Pryor for their careful reading of this paper. We thank all the families involved in this study.

\section{Conflict of Interest}

The authors declare that they have no conflict of interest 
[1] An overview of housing exclusion in europe. FEANTSA; 2015.

[2] Vandentorren S, Le Méner E, Oppenchaim N, Arnaud A, Jangal C, Caum C, et al. Characteristics and health of homeless families: the ENFAMS survey in the Paris region, France 2013. Eur J Public Health 2016;26:71-6. doi:10.1093/eurpub/ckv187.

[3] Guyavarch E, Le Mener E. Connaissances sur les personnes en famille sans logement personnel 2010.

[4] Guyavarch E, Le Mener E, Vandentorren S. ENFAMS : Enfants et familles sans logement personnel en lle-de-France : premiers résultats de l'enquête quantitative. Paris: Observatoire du Samu Social, Inserm; 2014.

[5] Schwartz CE, Kunwar PS, Hirshfeld-Becker DR, Henin A, Vangel MG, Rauch SL, et al. Behavioral inhibition in childhood predicts smaller hippocampal volume in adolescent offspring of parents with panic disorder. Transl Psychiatry 2015;5:e605. doi:10.1038/tp.2015.95.

[6] State MW, Lombroso PJ, Pauls DL, Leckman JF. The genetics of childhood psychiatric disorders: a decade of progress. J Am Acad Child Adolesc Psychiatry 2000;39:946-62. doi:10.1097/00004583-200008000-00006.

[7] Hirshfeld-Becker DR, Micco JA, Henin A, Petty C, Faraone SV, Mazursky H, et al. Psychopathology in adolescent offspring of parents with panic disorder, major depression, or both: a 10-year follow-up. Am J Psychiatry 2012;169:1175-84. doi:10.1176/appi.ajp.2012.11101514.

[8] Bassuk EL, Beardslee WR. Depression in Homeless Mothers: Addressing an Unrecognized Public Health Issue. J Orthopsychiatry 2014 2014;84:73-81. doi:10.1037/h0098949.

[9] Fazel S, Geddes JR, Kushel M. The health of homeless people in high-income countries: descriptive epidemiology, health consequences, and clinical and policy recommendations. The Lancet 2014;384:1529-40. doi:10.1016/S0140-6736(14)61132-6.

[10] Suglia SF, Duarte CS, Sandel MT. Housing Quality, Housing Instability, and Maternal Mental Health. J Urban Health Bull N Y Acad Med 2011;88:1105-16. doi:10.1007/s11524-011-9587-0.

[11] Grant R, Gracy D, Goldsmith G, Shapiro A, Redlener IE. Twenty-five years of child and family homelessness: where are we now? Am J Public Health 2013;103 Suppl 2:e1-10. doi:10.2105/AJPH.2013.301618.

[12] Conrad BS. Maternal depressive symptoms and homeless children's mental health: risk and resiliency. Arch Psychiatr Nurs 1998;12:50-8.

[13] Rutter M. Psychosocial resilience and protective mechanisms. Am J Orthopsychiatry 1987;57:316-31.

[14] Kuperman S, Schlosser SS, Lidral J, Reich W. Relationship of child psychopathology to parental alcoholism and antisocial personality disorder. J Am Acad Child Adolesc Psychiatry 1999;38:686-92. doi:10.1097/00004583-199906000-00015.

[15] Cutts DB, Coleman S, Black MM, Chilton MM, Cook JT, Cuba SE de, et al. Homelessness During Pregnancy: A Unique, Time-Dependent Risk Factor of Birth Outcomes. Matern Child Health J 2014;19:1276-83. doi:10.1007/s10995-014-1633-6.

[16] Bain M, Juszczak E, McInneny K, Kendell RE. Obstetric complications and affective psychoses. Two case-control studies based on structured obstetric records. Br J Psychiatry J Ment Sci 2000;176:523-6.

[17] Samuels J, Shinn M, Buckner JC. Homeless Children: Update on Research, Policy, Programs, and Opportunities 2010.

[18] Weinreb L, Wehler C, Perloff J, Scott R, Hosmer D, Sagor L, et al. Hunger: its impact on children's health and mental health. Pediatrics 2002;110:e41.

[19] Murali V, Oyebode F. Poverty, social inequality and mental health. Adv Psychiatr Treat 2004;10:216-24. doi:10.1192/apt.10.3.216.

[20] Amone-P'Olak K, Burger H, Ormel J, Huisman M, Verhulst FC, Oldehinkel AJ. Socioeconomic position and mental health problems in pre- and early-adolescents: the TRAILS study. Soc Psychiatry Psychiatr Epidemiol 2009;44:231-8. doi:10.1007/s00127-008-0424-z. 
[21] Bassuk EL, Buckner JC, Weinreb LF, Browne A, Bassuk SS, Dawson R, et al. Homelessness in female-headed families: childhood and adult risk and protective factors. Am J Public Health 1997;87:241-8.

[22] Rog DJ, Buckner JC. Homeless families and children. Paper presented at the 2007 national symposium on homelessness Research 2007.

[23] Buckner JC, Mezzacappa E, Beardslee WR. Characteristics of resilient youths living in poverty: the role of self-regulatory processes. Dev Psychopathol 2003;15:139-62.

[24] Bassuk EL, Rosenberg L. Why does family homelessness occur? A case-control study. Am J Public Health 1988;78:783-8.

[25] Bassuk EL. Who are the homeless families? Characteristics of sheltered mothers and children. Community Ment Health J 1990;26:425-34.

[26] Buckner JC, Beardslee WR, Bassuk EL. Exposure to violence and low-income children's mental health: direct, moderated, and mediated relations. Am J Orthopsychiatry 2004;74:413-23. doi:10.1037/0002-9432.74.4.413.

[27] Impact des violences sexuelles de l'enfance à l'âge adulte. Association mémoire traumatique et victimologie; 2015.

[28] Tursz A. Enfants maltraités. Les chiffres et leur base juridique en France. Tec \& Doc Lavoisier; 2008.

[29] Vostanis P, Tischler V, Cumella S, Bellerby T. Mental health problems and social supports among homeless mothers and children victims of domestic and community violence. Int J Soc Psychiatry 2001;47:30-40.

[30] Cummings JG, Pepler DJ, Moore TE. Behavior Problems in Children Exposed to Wife Abuse: Gender Differences. J Fam Violence 1999;14:133-56. doi:10.1023/A:1022024702299.

[31] Engle PL, Black MM. The effect of poverty on child development and educational outcomes. Ann N Y Acad Sci 2008;1136:243-56. doi:10.1196/annals.1425.023.

[32] Zima BT, Wells KB, Freeman HE. Emotional and behavioral problems and severe academic delays among sheltered homeless children in Los Angeles County. Am J Public Health 1994;84:260-4.

[33] Bassuk EL, Richard MK, Tsertsvadze A. The Prevalence of Mental Illness in Homeless Children: A Systematic Review and Meta-Analysis. J Am Acad Child Adolesc Psychiatry 2015;54:86-96.e2. doi:10.1016/j.jaac.2014.11.008.

[34] Shonkoff JP, Garner AS, Health TC on PA of C and F, Childhood C on E, Adoption, Care AD, et al. The Lifelong Effects of Early Childhood Adversity and Toxic Stress. Pediatrics 2011:peds.2011663. doi:10.1542/peds.2011-2663.

[35] Moore T, McArthur M, Noble-Carr D. Stuff you'd never think of Children talk about homelessness and how they'd like to be supported.pdf. Famiy Matters 2008.

[36] Buckner JC, Bassuk EL, Weinreb LF. Predictors of Academic Achievement among Homeless and Low-Income Housed Children. J Sch Psychol 2001;39:45-69. doi:10.1016/S00224405(00)00059-5.

[37] Fantuzzo JW, LeBoeuf WA, Chen C-C, Rouse HL, Culhane DP. The Unique and Combined Effects of Homelessness and School Mobility on the Educational Outcomes of Young Children. Educ Res 2012;41:393-402. doi:10.3102/0013189X12468210.

[38] Buckner JC. Understanding the Impact of Homelessness on Children Challenges and Future Research Directions. Am Behav Sci 2008;51:721-36. doi:10.1177/0002764207311984.

[39] Bassuk EL, Rubin L, Lauriat AS. Characteristics of sheltered homeless families. Am J Public Health 1986;76:1097-101.

[40] Goodman R. The Strengths and Difficulties Questionnaire: a research note. J Child Psychol Psychiatry 1997;38:581-6.

[41] Goodman R. Psychometric properties of the strengths and difficulties questionnaire. J Am Acad Child Adolesc Psychiatry 2001;40:1337-45. doi:10.1097/00004583-200111000-00015. 
[42] Mieloo CL, Bevaart F, Donker MCH, van Oort FVA, Raat $\mathrm{H}$, Jansen W. Validation of the SDQ in a multi-ethnic population of young children. Eur J Public Health 2014;24:26-32. doi:10.1093/eurpub/ckt100.

[43] Marzocchi GM, Capron C, Di Pietro M, Duran Tauleria E, Duyme M, Frigerio A, et al. The use of the Strengths and Difficulties Questionnaire (SDQ) in Southern European countries. Eur Child Adolesc Psychiatry 2004;13 Suppl 2:I140-6. doi:10.1007/s00787-004-2007-1.

[44] Martin-Fernandez J, Grillo F, Parizot I, Caillavet F, Chauvin P. Prevalence and socioeconomic and geographical inequalities of household food insecurity in the Paris region, France, 2010. BMC Public Health 2013;13:486. doi:10.1186/1471-2458-13-486.

[45] Radimer KL. Measurement of household food security in the USA and other industrialised countries. Public Health Nutr 2002;5:859-64. doi:10.1079/PHN2002385.

[46] Lefeuvre D, Delmas M-C, Marguet C, Chauvin P, Vandentorren S. Asthma-Like Symptoms in Homeless Children in the Greater Paris Area in 2013: Prevalence, Associated Factors and Utilization of Healthcare Services in the ENFAMS Survey. PloS One 2016;11:e0153872. doi:10.1371/journal.pone.0153872.

[47] Sheehan DV, Lecrubier Y, Sheehan KH, Amorim P, Janavs J, Weiller E, et al. The MiniInternational Neuropsychiatric Interview (M.I.N.I.): the development and validation of a structured diagnostic psychiatric interview for DSM-IV and ICD-10. J Clin Psychiatry 1998;59 Suppl 20:22-33;quiz 34-57.

[48] Kessler RC, Wittchen H-U, Abelson JM, Mcgonagle K, Schwarz N, Kendler KS, et al. Methodological studies of the Composite International Diagnostic Interview (CIDI) in the US national comorbidity survey (NCS). Int J Methods Psychiatr Res 1998;7:33-55. doi:10.1002/mpr.33.

[49] VIRAGE survey. Ined - Inst Natl D'études Démographiques n.d. https://www.ined.fr/en/everything_about_population/demographic-facts-sheets/focuson/virage-survey/ (accessed April 25, 2016).

[50] Shojaei T, Wazana A, Pitrou I, Kovess V. The strengths and difficulties questionnaire: validation study in French school-aged children and cross-cultural comparisons. Soc Psychiatry Psychiatr Epidemiol 2009;44:740-7. doi:10.1007/s00127-008-0489-8.

[51] Jaffe P, Wolfe D, Wilson SK, Zak L. Family violence and child adjustment: a comparative analysis of girls' and boys' behavioral symptoms. Am J Psychiatry 1986;143:74-7.

[52] Yu M, North CS, Lavesser PD, Osborne VA, Spitznagel EL. A comparison study of psychiatric and behavior disorders and cognitive ability among homeless and housed children. Community Ment Health J 2008;44:1-10. doi:10.1007/s10597-007-9100-0.

[53] Karim K, Tischler V, Gregory P, Vostanis P. Homeless children and parents: short-term mental health outcome. Int J Soc Psychiatry 2006;52:447-58.

[54] Menke EM. The Mental Health of Homeless School-Age Children. J Child Adolesc Psychiatr Nurs 1998;11:87-98. doi:10.1111/j.1744-6171.1998.tb00020.x.

[55] Bassuk E, Rubin L. Homeless children: a neglected population. Am J Orthopsychiatry 1987;57:279-86.

[56] Weissman MM, Wickramaratne P, Warner V, John K, Prusoff BA, Merikangas KR, et al. Assessing psychiatric disorders in children. Discrepancies between mothers' and children's reports. Arch Gen Psychiatry 1987;44:747-53.

[57] Hwang SW, Kirst MJ, Chiu S, Tolomiczenko G, Kiss A, Cowan L, et al. Multidimensional Social Support and the Health of Homeless Individuals. J Urban Health Bull N Y Acad Med 2009;86:791-803. doi:10.1007/s11524-009-9388-x.

[58] Lam JA, Rosenheck R. Social support and service use among homeless persons with serious mental illness. Int J Soc Psychiatry 1999;45:13-28.

[59] Letiecq BL, Anderson EA, Koblinsky SA. Social Support of Homeless and Permanently Housed Low-Income Mothers with Young Children. Fam Relat 1996;45:265. doi:10.2307/585498. 
[60] Nicholson J, Finkelstein N, Williams V, Thom J, Noether C, DeVilbiss M. A comparison of mothers with co-occurring disorders and histories of violence living with or separated from minor children. J Behav Health Serv Res 2006;33:225-43. doi:10.1007/s11414-006-9015-5.

[61] Langlois J, Fortin D. Single-parent mothers, poverty and mental health: review of the literature. Santé Ment Au Qué 1994;19:157-73.

[62] Vangeest JB, Johnson TP. Substance Abuse and Homelessness: Direct or Indirect Effects? Ann Epidemiol 2002;12:455-61. doi:10.1016/S1047-2797(01)00284-8.

[63] Stein JA, Leslie MB, Nyamathi A. Relative contributions of parent substance use and childhood maltreatment to chronic homelessness, depression, and substance abuse problems among homeless women: mediating roles of self-esteem and abuse in adulthood. Child Abuse Negl 2002;26:1011-27.

[64] Bassuk EL, Buckner JC, Perloff JN, Bassuk SS. Prevalence of mental health and substance use disorders among homeless and low-income housed mothers. Am J Psychiatry 1998;155:1561-4.

[65] Goodman R, Ford T, Simmons H, Gatward R, Meltzer H. Using the Strengths and Difficulties Questionnaire (SDQ) to screen for child psychiatric disorders in a community sample. $\mathrm{Br} J$ Psychiatry J Ment Sci 2000;177:534-9.

[66] Sarchiapone M, Mandelli L, Carli V, losue M, Wasserman C, Hadlaczky G, et al. Hours of sleep in adolescents and its association with anxiety, emotional concerns, and suicidal ideation. Sleep Med 2013. doi:10.1016/j.sleep.2013.11.780.

[67] Hoover JH, Oliver R, Hazler RJ. Bullying: Perceptions of Adolescent Victims in the Midwestern USA. Sch Psychol Int 1992;13:5-16. doi:10.1177/0143034392131001.

[68] Hoover JH, Oliver RL, Thomson KA. Perceived Victimization by School Bullies: New Research and Future Direction. J Humanist Educ Dev 1993;32:76-84. doi:10.1002/j.21644683.1993.tb00133.x.

[69] Tseliou F, Maguire A, Donnelly M, O'Reilly D. The impact of childhood residential mobility on mental health outcomes in adolescence and early adulthood: a record linkage study. J Epidemiol Community Health 2016;70:278-85. doi:10.1136/jech-2015-206123.

[70] Chaque enfant compte. Partout, tout le temps. Rapport alternatif 2015 de l'UNICEF France et de ses partenaires dans le cadre de l'audition de la France par le Comité des Droits de l'Enfant des Nations Unies. France: UNICEF; n.d.

[71] Pilowsky DJ, Wickramaratne P, Talati A, Tang M, Hughes CW, Garber J, et al. Children of depressed mothers 1 year after the initiation of maternal treatment: findings from the STAR*DChild Study. Am J Psychiatry 2008;165:1136-47. doi:10.1176/appi.ajp.2008.07081286.

[72] Wickramaratne P, Gameroff MJ, Pilowsky DJ, Hughes CW, Garber J, Malloy E, et al. Children of depressed mothers 1 year after remission of maternal depression: findings from the STAR*DChild study. Am J Psychiatry 2011;168:593-602. doi:10.1176/appi.ajp.2010.10010032.

[73] Shinn M, Schteingart JS, Williams NC, Carlin-Mathis J, Bialo-Karagis N, Becker-Klein R, et al. Long-Term Associations of Homelessness With Children's Well-Being. Am Behav Sci 2008;51:789-809. doi:10.1177/0002764207311988.

[74] -project $N$ on the D. Housing first in Finland 2011. http://www.housingfirst.fi/en/housing_first (accessed January 19, 2016).

[75] Résumé du rapport final du project pancanadien Chez Soi. Ment Health Comm Can n.d. http://www.mentalhealthcommission.ca/Francais/document/27511/executive-summary-crosssite-homechez-soi-project (accessed February 9, 2016).

[76] Council on Community Pediatrics. Providing care for children and adolescents facing homelessness and housing insecurity. Pediatrics 2013;131:1206-10. doi:10.1542/peds.20130645.

[77] Keogh C, O'Brien KK, Hoban A, O'Carroll A, Fahey T. Health and use of health services of people who are homeless and at risk of homelessness who receive free primary health care in Dublin. BMC Health Serv Res 2015;15:58. doi:10.1186/s12913-015-0716-4.

[78] SAMHSA News: Coordinating Care for Children with Serious Mental Health Challenges|SAMHSA 2009. 
[79] Guo X, Slesnick N, Feng X. Housing and Support Services with Homeless Mothers: Benefits to the Mother and Her Children. Community Ment Health J 2016;52:73-83. doi:10.1007/s10597015-9830-3.

[80] David DH, Gelberg L, Suchman NE. Implications of homelessness for parenting young children : a preliminary review from a developmental attachment perspective. Infant Ment Health J 2012;33:1-9. doi:10.1002/imhj.20333.

[81] Durlak JA, Wells AM. Primary Prevention Mental Health Programs for Children and Adolescents: A Meta-Analytic Review. Am J Community Psychol 1997;25:115-52. doi:10.1023/A:1024654026646.

[82] Becker KD, Bradshaw CP, Domitrovich C, lalongo NS. Coaching teachers to improve implementation of the good behavior game. Adm Policy Ment Health 2013;40:482-93. doi:10.1007/s10488-013-0482-8.

[83] Bradshaw CP, Zmuda JH, Kellam SG, lalongo NS. Longitudinal Impact of Two Universal Preventive Interventions in First Grade on Educational Outcomes in High School. J Educ Psychol 2009;101:926-37. doi:10.1037/a0016586.

[84] Eckenrode J, Ganzel B, Henderson CR, Smith E, Olds DL, Powers J, et al. Preventing child abuse and neglect with a program of nurse home visitation: the limiting effects of domestic violence. JAMA 2000;284:1385-91.

[85] Olds D, Henderson CR, Cole R, Eckenrode J, Kitzman H, Luckey D, et al. Long-term effects of nurse home visitation on children's criminal and antisocial behavior: 15-year follow-up of a randomized controlled trial. JAMA 1998;280:1238-44.

[86] Perlman S, Cowan B, Gewirtz A, Haskett M, Stokes L. Promoting positive parenting in the context of homelessness. Am J Orthopsychiatry 2012;82:402-12. doi:10.1111/j.19390025.2012.01158.x.

[87] Paquette K, Bassuk EL. Parenting and homelessness: overview and introduction to the Special Section. Am J Orthopsychiatry 2009;79:292-8. doi:10.1037/a0017245.

[88] Kolos AC, Green EJ, Crenshaw DA. Conducting filial therapy with homeless parents. Am J Orthopsychiatry 2009;79:366-74. doi:10.1037/a0017235.

[89] Kim-Cohen J, Caspi A, Moffitt TE, Harrington H, Milne BJ, Poulton R. Prior juvenile diagnoses in adults with mental disorder: developmental follow-back of a prospective-longitudinal cohort. Arch Gen Psychiatry 2003;60:709-17. doi:10.1001/archpsyc.60.7.709. 
Figure 1 - Parents's spoken language of children growing up in homeless families' in the Paris region and their parents' (ENFAMS survey 2013, age 4-12 years, $n=343$ )

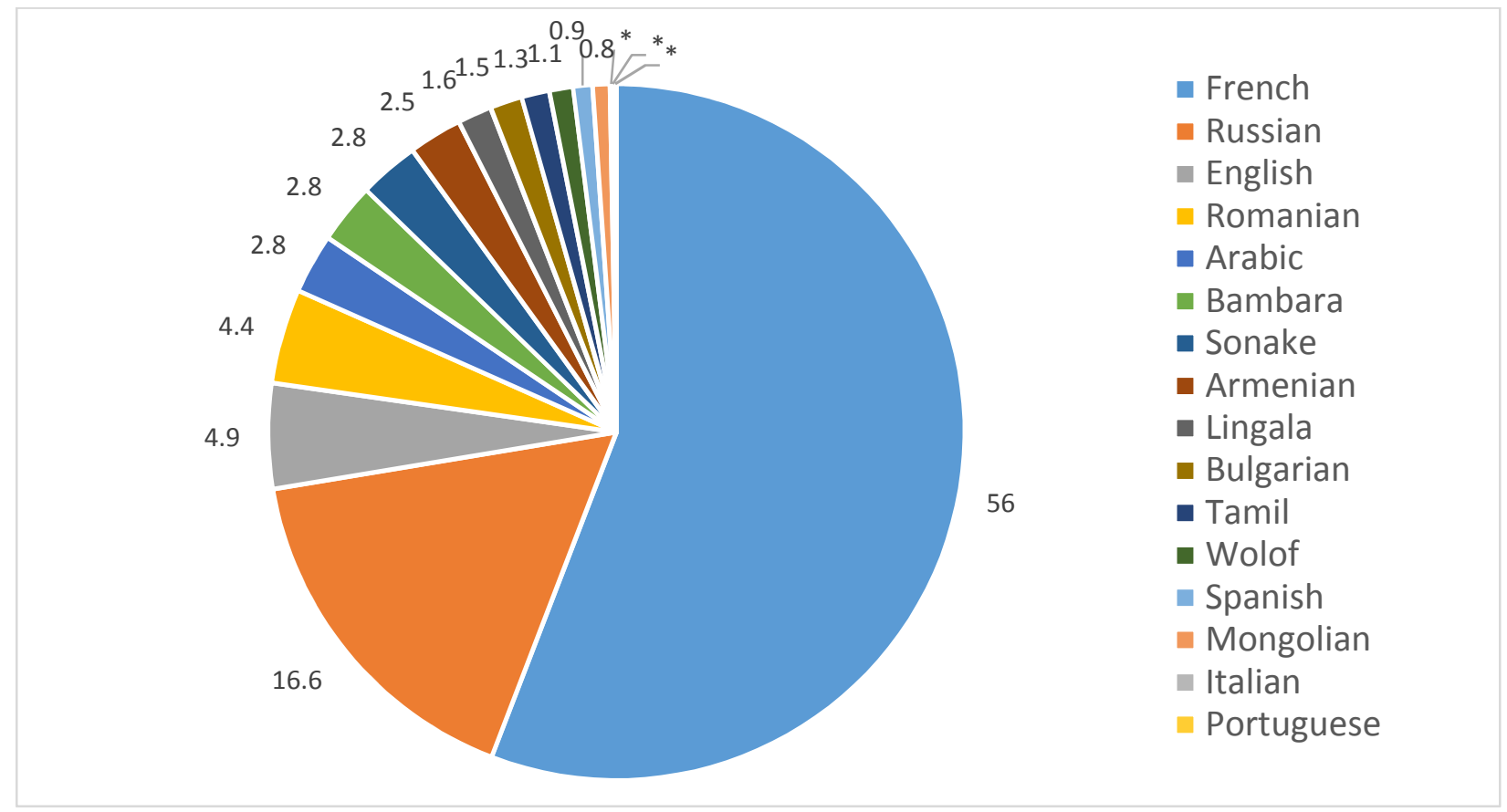

$* 0.1$ 
Figure 2 - Region of birth of children growing up in homeless families' in the Paris region and their parents' (ENFAMS survey 2013, age 4-12 years, $n=343$ )

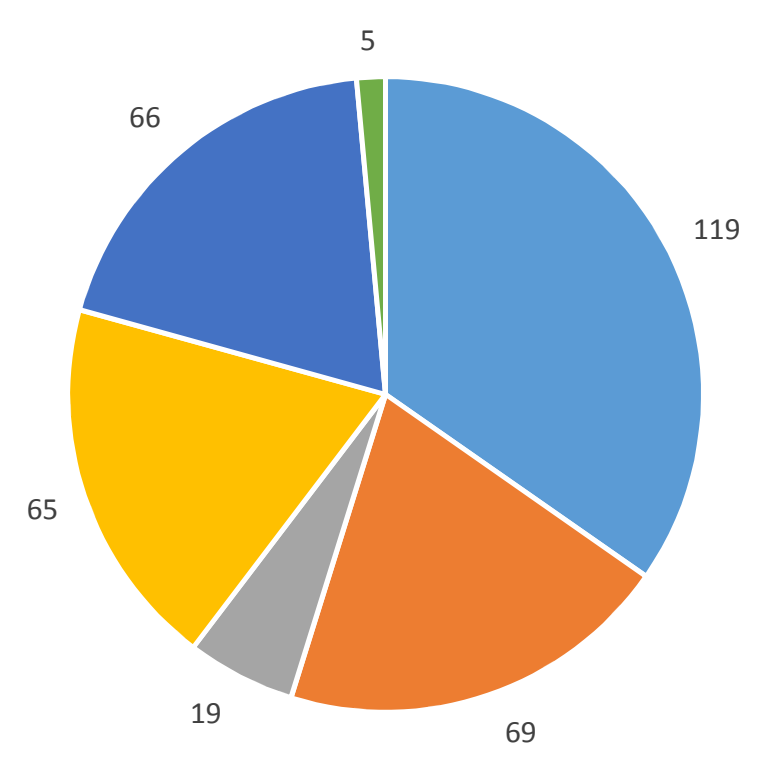

- France

- Sub-Saharan Africa

- North Africa

Eastern Europe

- Other countries

- Missing country of birth 
Table 1 - Parent's region of birth, of children growing up in homeless families' in the Paris region and their parents' (ENFAMS survey 2013, age 4-12 years, $n=343$ )

\begin{tabular}{llc}
\hline & Parent's region of birth & Prevalence (\%) \\
\hline \multirow{3}{*}{ Sub-Saharan Africa } & Central Africa & 13.1 \\
& West Africa & 29.2 \\
& East Africa & 1.9 \\
\hline North Africa & North Africa & 15.2 \\
\hline Eastern Europe & Eastern Europe & 21.1 \\
\hline \multirow{4}{*}{ Others } & South America & 0.1 \\
& Central Asia & 1.1 \\
& South Asia & 1.1 \\
& South-eastern Asia & 1.0 \\
& Western Asia & 9.8 \\
& Easten Asia & 0.6 \\
& Caribbean & 0.3 \\
& Southern Europe & 1.4 \\
& Western Europe & 4.0 \\
\hline
\end{tabular}


Table 2 - Characteristics of children growing up in homeless families' in the Paris region and their parents' (ENFAMS survey 2013, age 4-12 years, $n=343$ )

\begin{tabular}{|c|c|c|c|}
\hline & \\
\hline & $\mathrm{n}$ & $\begin{array}{c}\text { estimated } \\
\text { prevalence/mean }\end{array}$ & IC 95 \\
\hline Younger than 6 years & 116 & 34.5 & {$[28.4 ; 40.6]$} \\
\hline 6 years old and older & 227 & 65.5 & {$[59.4 ; 71.6]$} \\
\hline Girls & 180 & 52.8 & {$[46.1 ; 59.5]$} \\
\hline Boys & 163 & 47.2 & {$[40.5 ; 53.9]$} \\
\hline Number of cohabiting siblings & & 2.2 & {$[2.0 ; 2.4]$} \\
\hline Child born abroad & 219 & 55.5 & {$[47.5 ; 63.5]$} \\
\hline Child born in France & 119 & 42.8 & {$[34.7 ; 50.8]$} \\
\hline Missing country of birth & 5 & 1.7 & {$[0 ; 3.4]$} \\
\hline Schooled & 306 & 88.8 & {$[84.6 ; 93.1]$} \\
\hline Unnschooled & 35 & 10.1 & {$[6.3 ; 13.9]$} \\
\hline Missing schooling information & 2 & 1.1 & {$[-0.5 ; 2.6]$} \\
\hline Children without health problem that requires specific care & 287 & 82.2 & {$[75.7 ; 88.8]$} \\
\hline Children with health problem that requires specific care & 51 & 16 & {$[9.5 ; 22.5]$} \\
\hline Missing data on children's health & 5 & 1.8 & {$[0 ; 3.5]$} \\
\hline Children without respiratory problem & 225 & 64.2 & {$[57.9 ; 70.6]$} \\
\hline children with respiratory problem & 112 & 33.8 & {$[27.5 ; 40.0]$} \\
\hline Missing data on children's respiratory problem & 6 & 2.0 & {$[2.3 ; 3.8]$} \\
\hline No anemia, or light anemia & 235 & 70.1 & {$[62.4 ; 77.7]$} \\
\hline Moderate or hight anemia & 70 & 19.9 & {$[12.7 ; 27.0]$} \\
\hline Missing data on children's anemia & 38 & 10.1 & {$[6.1 ; 14.0]$} \\
\hline Thin or normal child's BMI & 234 & 65.3 & {$[58.2 ; 72.4]$} \\
\hline Overweight or obese child & 73 & 23.9 & {$[17.9 ; 29.9]$} \\
\hline Missing BMI & 36 & 10.8 & {$[5.9 ; 15.8]$} \\
\hline Bedtime before 10PM & 199 & 59.7 & {$[53.5 ; 66.0]$} \\
\hline Bedtime after 10PM & 100 & 26.3 & {$[20.6 ; 32.0]$} \\
\hline Missing bedtime data & 44 & 13.9 & {$[8.9 ; 18.9]$} \\
\hline Child's like of the family's accommodation & 155 & 68.4 & {$[61.5 ; 75.3]$} \\
\hline Child's dyslike of the family's accommodation & 57 & 27.3 & {$[20.6 ; 34.0]$} \\
\hline Missing data on family's accommodation & 9 & 4.3 & {$[1.3 ; 7.3]$} \\
\hline Child's inexperience of bullying & 145 & 67.1 & {$[58.7 ; 75.5]$} \\
\hline Child's experience of bullying & 49 & 26.4 & {$[18.5 ; 34.2]$} \\
\hline Missing data on experience of bullying & 8 & 6.5 & {$[0.1 ; 13.0]$} \\
\hline
\end{tabular}


Table 3 - Parents' characteristics of children growing up in homeless families' in the Paris region and their parents' (ENFAMS survey 2013, age 4-12 years, $n=343$ )

\begin{tabular}{|c|c|c|c|}
\hline & \\
\hline & $\mathrm{n}$ & $\begin{array}{c}\text { estimated } \\
\text { prevalence/mean }\end{array}$ & IC 95 \\
\hline Age & & 35.2 & {$[34.3 ; 36.1]$} \\
\hline Parent born in North Africa & 37 & 15.2 & {$[9.2 ; 21.2]$} \\
\hline Parent born in Sub-Saharan Africa & 157 & 44.2 & {$[37.9 ; 50.5]$} \\
\hline Parent born in Eastern Europe & 72 & 21.1 & {$[15.9 ; 26.2]$} \\
\hline Parent born in other countries & 77 & 19.5 & {$[15.1 ; 23.9]$} \\
\hline Legal residence status in France & 215 & 71.9 & {$[66.9 ; 76.9]$} \\
\hline Undocumented administrative status & 48 & 15.7 & {$[11.4 ; 20.1]$} \\
\hline Ongoing Asylum procedure & 59 & 12.3 & {$[9.0 ; 15.6]$} \\
\hline Missing data on administrative status & 1 & 0.1 & {$[-0.1 ; 0.3]$} \\
\hline Social hotel & 219 & 72.6 & {$[67.1 ; 78.1]$} \\
\hline Emergency housing centre & 24 & 3.5 & {$[1.9 ; 5.1]$} \\
\hline Housing facility for asylum-seekers & 46 & 4.5 & {$[3.5 ; 5.5]$} \\
\hline Long-term shelter & 54 & 19.4 & {$[13.8 ; 25.1]$} \\
\hline Two parent family & 174 & 50.6 & {$[44.4 ; 56.8]$} \\
\hline Single parent family & 169 & 49.4 & {$[43.2 ; 55.6]$} \\
\hline Medical insurance present & 264 & 76.5 & {$[58.8 ; 94.2]$} \\
\hline Medical insurance absent & 78 & 22.7 & {$[17.8 ; 27.6]$} \\
\hline Missing data on medical insurance & 1 & 0.7 & {$[-0.6 ; 2.1]$} \\
\hline Educational level $\geq$ high school & 167 & 45.7 & {$[39.9 ; 51.4]$} \\
\hline Educationel < high school & 165 & 50.6 & {$[44.6 ; 56.6]$} \\
\hline Missing data on educational level & 11 & 3.7 & {$[0.8 ; 6.7]$} \\
\hline Employed or in schooling & 84 & 31.1 & {$[25.1 ; 37]$} \\
\hline Neither employed nor in schooling & 258 & 68.2 & {$[62.1 ; 74.2]$} \\
\hline Missing data on employment status & 1 & 0.7 & {$[-0.6 ; 2.1]$} \\
\hline Not a proficient French speaker & 227 & 64.4 & {$[55.1 ; 73.7]$} \\
\hline Proficient French speaker & 106 & 35.6 & {$[26.3 ; 44.9]$} \\
\hline Income $<964$ euros/month/UC & 321 & 92.9 & {$[83.6 ; 102.3]$} \\
\hline Income $\geq 964$ euros/month/UC & 10 & 3.1 & {$[0.7 ; 5.5]$} \\
\hline Missing income data & 12 & 4.0 & {$[1.4 ; 6.7]$} \\
\hline Food insecure household & 281 & 84.0 & {$[78.9 ; 89]$} \\
\hline No food insecure household & 48 & 11.3 & {$[7.3 ; 15.3]$} \\
\hline Missing data on food insecurity & 14 & 4.7 & {$[1.3 ; 8.2]$} \\
\hline Welfare benefits & 135 & 37.0 & {$[31 ; 43.1]$} \\
\hline No welfare benefits & 208 & 63.0 & {$[56.9 ; 69]$} \\
\hline Number of moves since homeless (per year) & & 2.9 & {$[2.4 ; 3.4]$} \\
\hline Number of contacts with family members (per month) & & 12.4 & {$[9.5 ; 15.3]$} \\
\hline No negative life events in mother's life & 118 & 35.6 & {$[28.5 ; 42.7]$} \\
\hline Negative life events in mother's life & 204 & 58.0 & {$[50.4 ; 65.6]$} \\
\hline Missing data on negative life events & 21 & 6.4 & {$[3.1 ; 9.6]$} \\
\hline Mother without PTSD in the last 12 months & 252 & 74.7 & {$[69.5 ; 80]$} \\
\hline Mother with PTSD in the last 12 months & 68 & 18.5 & {$[13.5 ; 23.5]$} \\
\hline
\end{tabular}




\begin{tabular}{lccc} 
Missing data on maternal PTSD & 23 & 6.8 & {$[3.5 ; 10]$} \\
\hline Mother not depressed in the laste 12 months & 224 & 69.0 & {$[63.6 ; 74.5]$} \\
Mother depressed in the laste 12 months & 80 & 22.6 & {$[17.6 ; 27.6]$} \\
Missing data on maternal depression & 24 & 8.4 & {$[4.7 ; 12.1]$} \\
\hline Mother at risk of suicide in her life & 296 & 87.0 & {$[82.6 ; 91.4]$} \\
Mother not at risk of suicide in her life & 47 & 13.0 & {$[8.6 ; 17.4]$} \\
\hline No domestic violence in the last lé months & 214 & 61.3 & {$[55.7 ; 66.9]$} \\
Domestic violence in the last 12 months & 59 & 18.5 & {$[14 ; 22.9]$} \\
Missing data on domestic violence & 70 & 20.2 & {$[15.1 ; 25.4]$} \\
\hline Mother in good physical health & 289 & 88.2 & {$[83.9 ; 92.5]$} \\
Mother in poor physical health & 38 & 11.1 & {$[6.8 ; 15.3]$} \\
Missing data on maternal physical health & 1 & 0.8 & {$[-0.6 ; 2.2]$} \\
\hline
\end{tabular}


Table 4 - Emotional and behavioral difficulties (SDQ) of children growing up in homeless families' in the Paris region and their parents' (ENFAMS survey 2013, age 4-12 years, $n=343$ )

\begin{tabular}{llccc} 
& & $\mathrm{n}$ & $\begin{array}{c}\text { estimated } \\
\text { prevalence }\end{array}$ & IC 95 \\
\hline Total difficulties & Within normal range & 262 & 78.4 & {$[73.3 ; 83.5]$} \\
& High level & 78 & 20.8 & {$[15.8 ; 25.8]$} \\
& Missing data & 3 & 0.8 & {$[-0.4 ; 2]$} \\
\hline \multirow{2}{*}{ Emotional difficulties } & Within normal range & 228 & 71.4 & {$[66.1 ; 76.8]$} \\
& High level & 113 & 28.3 & {$[23 ; 33.6]$} \\
& Missing data & 2 & 0.2 & {$[-0.1 ; 0.6]$} \\
\hline Conduct problems & Within normal range & 264 & 76.1 & {$[69.3 ; 82.9]$} \\
& High level & 79 & 23.9 & {$[17.1 ; 30.7]$} \\
\hline \multirow{2}{*}{ Symptoms of hyperactivity-inattention } & Within normal range & 276 & 82.1 & {$[77.3 ; 86.8]$} \\
& High level & 66 & 17.7 & {$[13 ; 22.5]$} \\
& Missing data & 1 & 0.2 & {$[-0.1 ; 0.5]$} \\
\hline Peer relationship problems & Within normal range & 303 & 88.4 & {$[83.9 ; 93]$} \\
& High level & 37 & 10.7 & {$[6.5 ; 14.9]$} \\
& Missing data & 3 & 0.8 & {$[-0.4 ; 2]$} \\
\hline
\end{tabular}


Table 5 - Characteristic associated with emotional and behavioral difficulties in children growing up in homeless families in the Paris region (ENFAMS survey 2013, n=320, univariate linear regression analysis)

\begin{tabular}{|c|c|c|c|c|c|}
\hline & \multirow{2}{*}{$\begin{array}{l}\text { Weighted } \\
\text { prevalence/mean }\end{array}$} & \multicolumn{4}{|c|}{ Univariate model } \\
\hline & & Coefficient & IC 95 & $\mathbf{p}$ & p global \\
\hline Child's younger than 6 years & 35.4 & ref & & & 0.982 \\
\hline 6 to 12 years old child & 64.6 & -0.02 & {$[-1.95 ; 1.9]$} & 0.982 & \\
\hline Girls & 50.6 & ref & & & 0.043 \\
\hline Boys & 49.4 & 1.59 & {$[0.06 ; 3.12]$} & 0.043 & \\
\hline Number of cohabising siblings & & -0.83 & {$[-1.49 ;-0.16]$} & 0.016 & 0.016 \\
\hline Child born abroad & 55.5 & ref & & & 0.059 \\
\hline Child born in France & 45.5 & 1.67 & {$[-0.05 ; 3.39]$} & 0.059 & \\
\hline Parent's age (per 10 years) & & -0.82 & {$[-1.87 ; 0.22]$} & 0.126 & 0.126 \\
\hline Parent born in North Africa & 16.6 & ref & & & 0.016 \\
\hline Parent born in Sub-Saharan Africa & 46.6 & 2.22 & {$[-0.03 ; 4.47]$} & 0.055 & \\
\hline Parent born in Eastern Europe & 21.6 & 0.37 & {$[-1.99 ; 2.73]$} & 0.758 & \\
\hline Parent born in other countries & 15.1 & 3.43 & {$[0.91 ; 5.94]$} & 0.009 & \\
\hline Legal residence status in France & 51.4 & ref & & & 0.442 \\
\hline Undocumented administrative status & 37.9 & -0.98 & {$[-2.69 ; 0.73]$} & 0.262 & \\
\hline Ongoing Asylum procedure & 10.7 & -1.22 & {$[-3.72 ; 1.29]$} & 0.343 & \\
\hline Two parent family & 54.2 & ref & & & 0.276 \\
\hline Single parent family & 45.8 & -0.94 & {$[-2.63 ; 0.75]$} & 0.276 & \\
\hline Food insecure household & 84.2 & ref & & & 0.326 \\
\hline No food insecure household & 11.9 & -1.36 & {$[-3.25 ; 0.54]$} & 0.163 & \\
\hline Missing data on food insecurity & 3.9 & -1.29 & {$[-5.01 ; 2.43]$} & 0.499 & \\
\hline Number of moves since homeless (per year) & & 0.17 & {$[-0.01 ; 0.35]$} & 0.067 & 0.067 \\
\hline Number of contacts with family members (per month) & & 0.08 & {$[0.05 ; 0.12]$} & $<0.001$ & $<0.001$ \\
\hline No negative life events in mother's life & 37.4 & ref & & & 0.121 \\
\hline Negative life events in mother's life & 55.8 & 1.94 & {$[0.09 ; 3.78]$} & 0.042 & \\
\hline Missing data on negative life events & 6.7 & 0.99 & {$[-1.52 ; 3.49]$} & 0.442 & \\
\hline $\begin{array}{l}\text { Children without health problem that requires specific } \\
\text { care }\end{array}$ & 84.7 & ref & & $<0.001$ & $<0.001$ \\
\hline Children with health problem that requires specific care & 15.3 & 3.19 & {$[1.61 ; 4.77]$} & & \\
\hline Children without respiratory problem & 66.7 & ref & & & 0.001 \\
\hline children with respiratory problem & 33.0 & 1.69 & {$[0.02 ; 3.37]$} & 0.050 & \\
\hline Missing data on children's respiratory problem & 0.3 & -0.78 & {$[-1.79 ; 0.22]$} & 0.127 & \\
\hline No anemia, or light anemia & 70.6 & ref & & & 0.759 \\
\hline Moderate or hight anemia & 20.0 & 0.18 & {$[-1.58 ; 1.94]$} & 0.839 & \\
\hline Missing data on children's anemia & 9.4 & -0.79 & {$[-3.15 ; 1.57]$} & 0.512 & \\
\hline Thin or normal child's BMI & 65.6 & ref & & & 0.031 \\
\hline Overweight or obese child & 23.6 & 2.02 & {$[-0.07 ; 4.11]$} & 0.060 & \\
\hline Missing BMI & 10.8 & -1.37 & {$[-3.43 ; 0.68]$} & 0.192 & \\
\hline Bedtime before 10PM & 62.4 & ref & & & 0.043 \\
\hline Bedtime after 10PM & 25.5 & 2.18 & {$[0.48 ; 3.88]$} & 0.013 & \\
\hline Missing bedtime data & 12.1 & 0.85 & {$[-2.34 ; 4.04]$} & 0.600 & \\
\hline Mother not depressed in the last 12 months & 68.2 & ref & & & 0.004 \\
\hline Mother depressed in the last 12 months & 23.0 & 3.28 & {$[1.4 ; 5.16]$} & 0.001 & \\
\hline Missing data on maternal depression & 8.7 & 1.21 & {$[-1.27 ; 3.7]$} & 0.341 & \\
\hline Mother without PTSD in the last 12 months & 74.3 & ref & & & 0.077 \\
\hline Mother with PTSD in the last 12 months & 18.5 & 2.29 & {$[0.31 ; 4.28]$} & 0.026 & \\
\hline Missing data on maternal PTSD & 7.1 & 0.10 & {$[-2.05 ; 2.26]$} & 0.925 & \\
\hline
\end{tabular}




\begin{tabular}{|c|c|c|c|c|c|}
\hline Mother at risk of suicide in her life & 87.3 & ref & & & $<0.001$ \\
\hline Mother not at risk of suicide in her life & 12.7 & 5.79 & {$[2.99 ; 8.58]$} & $<0.001$ & \\
\hline No domestic violence in the last $\mathbf{1 2}$ months & 58.2 & ref & & & 0.177 \\
\hline Domestic violence in the last 12 months & 18.8 & 2.20 & {$[-0.26 ; 4.66]$} & 0.082 & \\
\hline Missing data on domestic violence & 22.9 & 0.89 & {$[-0.92 ; 2.7]$} & 0.335 & \\
\hline Mother in good physical health & 89.8 & ref & & & 0.011 \\
\hline Mother in poor physical health & 10.2 & 3.57 & {$[0.86 ; 6.29]$} & 0.011 & \\
\hline Child's like of the family's accommodation & 69.3 & ref & & & $<0.001$ \\
\hline Child's dyslike of the family's accommodation & 24.6 & 4.89 & {$[2.85 ; 6.93]$} & $<0.001$ & \\
\hline Missing data on family's accommodation & 6.0 & 2.05 & {$[0.11 ; 3.99]$} & 0.041 & \\
\hline Child's inexperience of bullying & 59.4 & ref & & & $<0.001$ \\
\hline Child's experience of bullying & 25.3 & 5.25 & {$[3.21 ; 7.29]$} & $<0.001$ & \\
\hline Missing data on experience of bullying & 15.3 & 1.28 & {$[-0.32 ; 2.88]$} & 0.118 & \\
\hline
\end{tabular}


Table 6 - Characteristic associated with emotional and behavioral difficulties in children growing up in homeless families in the Paris region (ENFAMS survey 2013, n=320, multivariate linear regression analysis)

\begin{tabular}{|c|c|c|c|c|c|}
\hline & \multirow{2}{*}{$\begin{array}{c}\text { Weighted } \\
\text { prevalence/mean }\end{array}$} & \multicolumn{4}{|c|}{ Univariate model } \\
\hline & & Coefficient & IC 95 & p & pglobal \\
\hline Child's younger than 6 years & 35.4 & ref & & & 0.056 \\
\hline 6 to 12 years old child & 64.6 & 4.31 & {$[-0.06 ; 8.69]$} & 0.056 & \\
\hline Girls & 50.6 & ref & & & 0.167 \\
\hline Boys & 49.4 & 0.84 & {$[-0.34 ; 2.02]$} & 0.167 & \\
\hline Number of cohabiting siblings & & -0.32 & {$[-0.88 ; 0.24]$} & 0.268 & 0.268 \\
\hline Child born abroad & 55.5 & ref & & & 0.510 \\
\hline Child born in France & 45.5 & 0.57 & {$[-1.13 ; 2.27]$} & 0.510 & \\
\hline Parent's age (per 10 years) & & -0.14 & {$[-1.12 ; 0.84]$} & 0.780 & 0.780 \\
\hline Parent born in North Africa & 16.6 & ref & & & 0.020 \\
\hline Parent born in Sub-Saharan Africa & 46.6 & 1.74 & {$[-0.14 ; 3.62]$} & 0.072 & \\
\hline Parent born in Eastern Europe & 21.6 & 0.60 & {$[-1.76 ; 2.95]$} & 0.622 & \\
\hline Parent born in other countries & 15.1 & 3.22 & {$[1.04 ; 5.39]$} & 0.005 & \\
\hline Legal residence status in France & 51.4 & ref & & & 0.975 \\
\hline Undocumented administrative status & 37.9 & -0.15 & {$[-1.6 ; 1.3]$} & 0.835 & \\
\hline Ongoing Asylum procedure & 10.7 & -0.16 & {$[-2.32 ; 1.99]$} & 0.881 & \\
\hline Number of moves since homeless (per year) & & 0.22 & {$[0.05 ; 0.38]$} & 0.012 & 0.012 \\
\hline Number of contacts with family members (per month) & & 0.03 & {$[0 ; 0.06]$} & 0.090 & 0.090 \\
\hline Children without health problem that requires specific care & 84.7 & ref & & & $<0.001$ \\
\hline Children with health problem that requires specific care & 15.3 & 3.49 & {$[2 ; 4.97]$} & $<0.001$ & \\
\hline Children without respiratiry problem & 33.1 & ref & & & 0.095 \\
\hline Children with respiratory problem & 66.9 & 1.05 & {$[-0.17 ; 2.28]$} & 0.095 & \\
\hline Thin or normal child's BMI & 65.6 & ref & & & 0.007 \\
\hline Overweight or obese child & 23.6 & 2.14 & {$[0.54 ; 3.75]$} & 0.010 & \\
\hline Missing BMI & 10.8 & -0.89 & {$[-2.62 ; 0.85]$} & 0.319 & \\
\hline Bed time before 10PM & 62.4 & ref & & & 0.002 \\
\hline Bed time after 10PM & 25.5 & 2.82 & {$[1.43 ; 4.21]$} & $<0.001$ & \\
\hline Missing bed time data & 12.1 & 1.82 & {$[-0.57 ; 4.21]$} & 0.138 & \\
\hline Mother not depressed in the last 12 months & 68.2 & ref & & & 0.393 \\
\hline Mother depressed in the last 12 months & 23.0 & -0.10 & {$[-1.77 ; 1.57]$} & 0.907 & \\
\hline Missing data on maternal depression & 8.7 & 2.30 & {$[-1.03 ; 5.63]$} & 0.178 & \\
\hline Mother without ptsd in the last 12 months & 74.3 & ref & & & 0.248 \\
\hline Mother with pstd in the last 12 months & 18.5 & 1.12 & {$[-0.62 ; 2.86]$} & 0.212 & \\
\hline Missing data on maternal ptsd & 7.1 & -1.92 & {$[-5.68 ; 1.85]$} & 0.321 & \\
\hline Mother at risk of suicide in her life & 87.3 & ref & & & $<0.001$ \\
\hline Mother not at risk of suicide in her life & 12.7 & 4.13 & {$[1.98 ; 6.28]$} & $<0.001$ & \\
\hline No domestic violence in the last 12 months & 58.2 & ref & & & 0.115 \\
\hline Domestic violence in the last 12 months & 18.8 & 0.67 & {$[-0.9 ; 2.23]$} & 0.405 & \\
\hline Missing data on domestic violence & 22.9 & 1.83 & {$[0.03 ; 3.64]$} & 0.050 & \\
\hline Mother in good physical health & 89.8 & ref & & & 0.100 \\
\hline Mother in poor physical health & 10.2 & 1.60 & {$[-0.29 ; 3.5]$} & 0.100 & \\
\hline Child's like of the family's accommodation & 69.3 & ref & & & $<0.001$ \\
\hline Child's dyslike of the family's accommodation & 24.6 & 3.59 & {$[1.78 ; 5.41]$} & $<0.001$ & \\
\hline Missing data on family's accommodation & 6.0 & 6.23 & {$[2.31 ; 10.15]$} & 0.002 & \\
\hline Child's inexperience of bullying & 59.4 & ref & & & 0.002 \\
\hline Child's experience of bullying & 25.3 & 3.21 & {$[1.29 ; 5.12]$} & 0.001 & \\
\hline Missing data on experience of bullying & 15.3 & -0.01 & {$[-1.97 ; 1.94]$} & 0.990 & \\
\hline
\end{tabular}


